\title{
Neurological Manifestations in Egyptian Covid-19 Patients
}

*Corresponding Author:

Ahmed Essmat

ahmadesmat81@yahoo.com

Received for publication November 16, 2020; Accepted january 23, 2021, Published online january 23, 2021.

\section{Copyright 2020 The Authors published by Al-Azhar University, Faculty of Medicine, Cairo, Egypt. All rights reserved. This an open- access article distributed under the legal terms, where it is permissible to download and share the work provided it is properly cited. The work cannot be changed in anyway or used commercially. \\ doi: $10.21608 /$ aimj.2021.49994.1352 \\ Neurology Department, Faculty of Medicine, Al-Azhar University, Cairo, Egypt.}

Disclosure: The authors have no financial interest to declare in relation to the content of this article. The Article Processing Charge was paid for by the authors.

Authorship: All authors have a substantial contribution to the article.

\section{Ahmed Essmat MD.}

\begin{abstract}
Background: The current Covid-19 pandemic massively overwhelmed the health scene in almost all world countries including Egypt. Neurological manifestations are commonly reported among Covid-19 patients.

Aim of work: to describe the neurological manifestations in a group of Egyptian patients diagnosed with Covid-19.

Patients and Methods: The present retrospective study was conducted at Al-Azhar University Hospitals. Patients included in the study comprised 50 patients with variable new-onset neurological manifestations in addition to other 50 patients without neurological manifestations recruited from other departments. All participants were subjected to careful history taking, thorough clinical examination and routine laboratory investigations. Patients with neurological manifestations were in addition submitted to computed tomography (CT) or magnetic resonance imaging (MRI) as appropriate. The primary outcome of the present study is patients' in-hospital mortality.

Results: Comparison between both groups shows that patients with neurological affection are significantly older $(54.7 \pm 12.8$ versus $44.2 \pm$ 18.8 years, $\mathrm{p}=0.002)$ with significantly higher $\mathrm{BMI}(32.4 \pm 7.8$ versus $\left.26.3 \pm 6.5 \mathrm{~kg} / \mathrm{m}^{\wedge} 2, \mathrm{p}<0.001\right)$. The reported neurological manifestations included headache $(78.0 \%)$ taste and smell impairment $(74.0 \%)$, myalgia $(62.0 \%)$ and dizziness $(58.0 \%)$. It was also shown that 30 patients $(60.0 \%)$ died among patients with neurological affection while in patients without neurological affection only 13 patients $(26.0 \%)$ died $(\mathrm{p}=0.001)$. Neurological manifestations are independent predictor of mortality [OR (95\% CI): 0.35 (0.14-0.88), $\mathrm{p}=0.025]$.

Conclusion: Neurological manifestations are common in Covid-19 patients. There is a significant association between the presence of neurological manifestations and mortality.
\end{abstract}

Keywords: Covid-19; Neurological manifestations; Covi-19 mortality.

\section{INTRODUCTION}

The current Covid-19 pandemic is the most drastic global health problem since the influenza pandemic that dominated the international scene after World War I and killed tens of millions of people in many countries . ${ }^{1}$ The pandemic is caused by severe acute respiratory syndrome coronavirus 2 (SARS-CoV-2). The causative pathogen showed distinctive neurological neurotropism in a large proportion of patients . ${ }^{2}$

It has been estimated that about one quarter of Covid-19 patients had one or more neurological symptoms. The range of neurological symptoms in covid-19 patients affect both the central and peripheral nervous systems. Reported manifestations include loss of taste and smell, headache, dizziness, Guillain-Barre syndrome, seizures, stroke and encephalitis . ${ }^{3}$

The relatively high frequency of neurological sequelae together with the wide spectrum of symptoms raised significant concern. Some authors suggested this may be related to compromised brainlung-brain axis that facilitates induction of brain injury as a result of concurrent lung injury. The central nervous system may be also affected by the overwhelming cytokine storm known as the hallmark of covid-19 pathogenicity ${ }^{4}$ Other contributing factors are blood pressure dysregulation, hypoxia and thrombotic complications..$^{5}$

Direct viral invasion was suggested via angiotensinconverting enzyme two receptors present on endothelial cells of cerebral vessels ${ }^{6}$ Other possible routes of neurological involvement include anterograde and retrograde transport along peripheral nerves and the hematological route ${ }^{7}$

Neurological involvement in Covid-19 patients carries a bad prognostic indication. It was associated with more frequent need of mechanical ventilation and higher risk of mortality. ${ }^{8}$

The aim of the present study is to describe the neurological manifestations in a group of Egyptian patients diagnosed with Covid-19. 


\section{PATIENTE AND METHODS}

The present retrospective study was conducted at AlAzhar University Hospitals in the period from April, 2020 through July, 2020. The study protocol was approved by the local ethical committee. The study included Covid-19 patients diagnosed on the basis of PCR examination according to the Egyptian Ministry of Health protocol. Patients included in the study comprised 50 patients with variable new-onset neurological manifestations in addition to other 50 patients without neurological manifestations recruited from other departments. Patients were excluded if they reported similar neurological manifestations before or if they had previous severe clinical illness e.g. hepatic failure, renal failure, heart failure or malignancy.

All participants were subjected to careful history taking, thorough clinical examination and routine laboratory investigations. Patients with neurological manifestations were in addition submitted to computed tomography (CT) or magnetic resonance imaging (MRI) as appropriate. Severity of Covid-19 illness was assessed according to the recommendations of Infectious Diseases Society of America/American Thoracic Society Criteria. Patients were classified to have severe disease if they have at least one of two major criteria (septic shock with need for vasopressors or invasive mechanical ventilation) or $\geq 3$ minor criteria (respiratory rate $\geq$ 30 breaths $/ \mathrm{min}$, pao $/$ fio 2 ratio $\leq 250$, multilobar infiltrates, confusion/disorientation, uremia (bun level $\geq 20 \mathrm{mg} / \mathrm{dl}$ ), leukopenia as a result to infection alone (WBC count $<4,000 \quad$ cells $/ \mathrm{ml}$ ), thrombocytopenia (platelets $<100,000 / \mathrm{ml}$ ), hypothermia (core temperature $<36^{\circ} \mathrm{C}$ ), hypotension requiring aggressive fluid resuscitation) . ${ }^{9}$ The primary outcome of the present study is patients' inhospital mortality

Data obtained from the present study were presented as mean and standard deviation (SD) or number and percent. Categorical data were compared using chisquare test or Fisher's exact test while numerical data were compared using student $t$ test. Logistic regression analysis was used to identify predictors of mortality in the studied patients. All statistical operations were computed using SPSS 26 (IBM, IL, USA). $P$ value was considered statistically significant.

\section{RESULTS}

The present study included 100 patients with Covid19 infection. They comprised 50 patients with neurological symptoms and 50 patients without neurological symptoms. Comparison between both groups shows that patients with neurological affection are significantly older $(54.7 \pm 12.8$ versus $44.2 \pm 18.8$ years, $\mathrm{p}=0.002$ ) with significantly higher BMI $\left(32.4 \pm 7.8\right.$ versus $26.3 \pm 6.5 \mathrm{~kg} / \mathrm{m}^{\wedge} 2$, $\left.\mathrm{p}<0.001\right)$. In addition, they had significantly higher frequency of previous pulmonary morbidities $(34.0 \%$ versus $14.0 \%, \mathrm{p}=0.016)($ Table-1).

\begin{tabular}{|c|c|c|c|}
\hline & $\begin{array}{c}\text { Neurological } \\
\text { manifestations } \\
+ \text { ve } \\
\mathrm{N}=50\end{array}$ & $\begin{array}{c}\text { Neurological } \\
\text { manifestations } \\
+ \text { ve } \\
\mathrm{N}=50\end{array}$ & $P$ value \\
\hline $\begin{array}{l}\text { Age (years) } \\
\text { mean } \pm \text { SD }\end{array}$ & $54.7 \pm 12.8$ & $44.2 \pm 18.8$ & 0.002 \\
\hline Male/female $n$ & $33 / 17$ & $24 / 26$ & 0.067 \\
\hline $\begin{array}{l}\text { BMI } \\
\left(\mathrm{Kg} / \mathrm{m}^{\wedge} 2\right) \\
\text { mean } \pm \mathrm{SD}\end{array}$ & $32.4 \pm 7.8$ & $26.3 \pm 6.5$ & $<0.001$ \\
\hline \multicolumn{4}{|c|}{ Associated comorbidities n (\%) } \\
\hline Hypertension & $20(40.0)$ & $26(52.0)$ & 0.23 \\
\hline Cardiac & $18(36.0)$ & $22(44.0)$ & 0.46 \\
\hline Renal & $15(30.0)$ & $9(18.0)$ & 0.39 \\
\hline Pulmonary & $17(34.0)$ & $7(14.0)$ & 0.016 \\
\hline Diabetes & $25(50.0)$ & $21(42.0)$ & 0.42 \\
\hline Hepatic & $10(20.0)$ & $7(14.0)$ & 0.42 \\
\hline \multicolumn{4}{|c|}{ Covid-19 severity } \\
\hline Severe & $20(40.0)$ & $18(36.0)$ & \multirow{2}{*}{0.68} \\
\hline Non-severe & $30(60.0)$ & $32(64.0)$ & \\
\hline
\end{tabular}

Table 1: Comparison between patients with neurological manifestations and patients without regarding the baseline data

The reported neurological manifestations included headache $(78.0 \%)$ taste and smell impairment $(74.0$ $\%)$, myalgia $(62.0 \%)$ and dizziness $(58.0 \%)$ (Table2).

\begin{tabular}{|c|c||}
\hline & $\mathrm{n}(\%)$ \\
\hline Dizziness & $29(58.0)$ \\
\hline Headache & $39(78.0)$ \\
\hline Altered mental status & $26(52.0)$ \\
\hline Stroke & $20(40.0)$ \\
\hline Gait imbalance & $20(40.0)$ \\
\hline Seizures & $9(18.0)$ \\
\hline Taste impairment & $37(74.0)$ \\
\hline Smell impairment & $37(74.0)$ \\
\hline Vision impairment & $19(38.0)$ \\
\hline Nerve pain & $10(20.0)$ \\
\hline Myalgia & $31(62.0)$ \\
\hline Rhabdomyolysis & $17(34.0)$ \\
\hline
\end{tabular}

Table 2: Distribution of neurological manifestations in the studied patients

\begin{tabular}{|l|c|c|c|c|c|c|}
\hline \multirow{2}{*}{} & \multicolumn{3}{|c|}{ Univariate analysis } & \multicolumn{3}{c|}{ Multivariate analysis } \\
\cline { 2 - 7 } & OR & $\begin{array}{c}95 \% \\
\text { CI }\end{array}$ & P & OR & $\begin{array}{c}95 \% \\
\text { CI }\end{array}$ & P \\
\hline Age & 1.01 & $\begin{array}{c}0.99- \\
1.04\end{array}$ & 0.34 & - & - & - \\
\hline Sex & 0.39 & $\begin{array}{c}0.17- \\
0.9\end{array}$ & 0.027 & 2.40 & $\begin{array}{c}0.96- \\
5.8\end{array}$ & 0.06 \\
\hline BMI & 1.08 & $\begin{array}{c}1.02- \\
1.1\end{array}$ & 0.011 & 1.05 & $\begin{array}{c}0.99- \\
1.1\end{array}$ & 0.1 \\
\hline Pulmonary & 0.86 & $0.34-$ & 0.75 & - & - & - \\
affection & & 2.16 & & & & \\
\hline Neurological \\
affection
\end{tabular}

Table 3: Predictors of mortality in the studied patients

It was also shown that 30 patients $(60.0 \%)$ in died among patients with neurological affection while in patients without neurological affection only 13 patients $(26.0 \%)$ died $(\mathrm{p}=0.001)$. Logistic regression analysis identified presence of neurological manifestations as an independent predictor of mortality [OR (95\% CI): 0.35 (0.14-0.88), $\mathrm{p}=0.025]$. 


\section{DISCUSSION}

The present study aimed to describe the neurological manifestations in a group of Covid-19 patients. In addition, we made a head-to head comparison between Covid-19 patients with neurological affection and other Covid-19 patients without neurological affection. In the present study, patients with neurological affection are significantly older with significantly higher BMI. In addition, they had significantly higher frequency of previous pulmonary morbidities. This is in line with the study of Romagnolo et al., ${ }^{10}$ who noted that Covid-19 patients with neurological disorders are significantly older than those without neurological affection.

In the present study, headache was the most common central CNS manifestation while smell and taste impairment were the commonest manifestations affecting the peripheral nervous system (PNS). These findings are in agreement with the study of Agarwal et al. ${ }^{11}$ However, in the study of Makda et al. ${ }^{12}$ the most common CNS manifestation was dizziness. In one meta-analysis, the commonest symptom affecting the CNS was headache while the commonest symptoms affecting the PNS was smell disturbance in agreement with our conclusions. ${ }^{13}$

Importantly, the present study identified the presence of neurological manifestations as an independent predictor of mortality in the studied patients. The association between neurological manifestations and poor outcome in Covid-19 patients were reported by other studies.$^{14}$ The systematic review and metaanalysis of Chua et al., ${ }^{15}$ also identified the presence of neurological symptoms as a bad prognostic element in Covid-19 patients.

\section{CONCLUSION}

the present study showed that neurological manifestations are common in Covid-19 patients. There is a significant association between the presence of neurological manifestations and mortality.

\section{REFERENCES}

1. Ellul MA, Benjamin L, Singh B, et al. Neurological associations of COVID-19. The Lancet. Neurology $.2020 ;$; 19(9):767-83 doi:10.1016/s14744422(20)30221-0

2. Beghi E, Feigin V, Caso V, Santalucia P, Logroscino G. COVID-19 Infection and Neurological Complications: Present Findings and Future Predictions. Neuroepidemiology. 2020;54(5):364-69 doi: 10.1159/000508991

3. Soltani Zangbar H, Gorji A, Ghadiri T. A Review on the Neurological Manifestations of COVID-19 Infection: a Mechanistic View. Molecular neurobiology. 2020:1-14 doi: 10.1007/s12035-02002149-0
4. Nuzzo D, Picone P. Potential neurological effects of severe COVID-19 infection. Neuroscience research. 2020;158:1-5 doi: 10.1016/j.neures.2020.06.009

5. Wenting A, Gruters A, van Os Y, et al. COVID-19 Neurological Manifestations and Underlying Mechanisms: A Scoping Review. Frontiers in psychiatry. 2020;11:860 doi: 10.3389/fpsyt.2020.00860

6. Garg RK. Spectrum of Neurological Manifestations in Covid-19: A Review. Neurology India. 2020;68(3):560-72 doi: 10.4103/0028-3886.289000

7. Yavarpour-Bali H, Ghasemi-Kasman M. Update on neurological manifestations of COVID-19. Life sciences. 2020;257:118063 doi: 10.1016/j.lfs.2020.118063

8. Khatoon F, Prasad K, Kumar V. Neurological manifestations of COVID-19: available evidences and a new paradigm. Journal of neurovirology. 2020;26(5):619-30 doi:10.1007/s13365-020-00895-4

9. Metlay JP, Waterer GW, Long AC, et al. Diagnosis and Treatment of Adults with Community-acquired Pneumonia. An Official Clinical Practice Guideline of the American Thoracic Society and Infectious Diseases Society of America. American journal of respiratory and critical care medicine. 2019;200(7):e45-e67 doi: 10.1164/rccm.2019081581ST

10. Romagnolo A, Balestrino R, Imbalzano G, et al. Neurological comorbidity and severity of COVID19. Journal of neurology. 2020;1-8 doi: 10.1007/s00415-020-10123-y

11. Agarwal P, Ray S, Madan A, Tyson B. Neurological manifestations in 404 COVID-19 patients in Washington State. Journal of neurology 2020:1-3 doi: 10.1007/s00415-020-10087-Z

12. Makda A, Kumar S, Kumar A, Kumar V, Rizwan A. The Frequency of Neurological Symptoms in COVID-19 Patients at a Tertiary Care Hospital in Pakistan. Cureus 2020;12(9):e10360 doi: 10.7759/cureus. 10360

13. Favas TT, Dev P, Chaurasia RN, et al. Neurological manifestations of COVID-19: a systematic review and meta-analysis of proportions. Neurological sciences : official journal of the Italian Neurological Society and of the Italian Society of Clinical Neurophysiology 2020;41(12):3437-70 doi: 10.1007/s10072-020-04801-y

14. Shekhar R, Sheikh AB, Suriya SS, Upadhyay S, Zafar A. Neurological Complications Among Native Americans with COVID-19: Our Experience at a Tertiary Care Academic Hospital in the U.S. Journal of stroke and cerebrovascular diseases : the official journal of National Stroke Association 2020;29(12):105260 10.1016/j.jstrokecerebrovasdis.2020.105260

15. Chua TH, Xu Z, King NKK. Neurological manifestations in COVID-19: a systematic review and meta-analysis. Brain injury 2020:1-20 doi: 10.1080/02699052.2020.1831606 